\title{
PROSEDUR ANALISIS KESALAHAN BERBAHASA
}

\author{
oleh Dawud \\ FS Univeristas Negeri Malang
}

\begin{abstract}
An error in language use is an instance of using language in a way which diverges from the norms of the target language. Such errors are natural phenomena in the process of language learning. Analyses of such errors have three important functions: a pedagogical function, a methodological function, and a facilitative function in a process of language acquisition. Such an analysis is done by going through the procedure of collecting language learners' language samples, identifying the errors, then describing them, and finally explaining them.
\end{abstract}

Keywords: errors in language use, error analysis, contrastive analysis

\section{A. PENDAHULUAN}

Pelajar-bahasa bahasa, baik anak maupun dewasa, dapat melakukan kesalahan berbahasa. Kesalahan berbahasa yang terjadi dapat berupa kesalahan pemahaman atau kesalahan produksi bahasa. Kesalahan berbahasa dapat terjadi pada pelajar-bahasa yang sedang belajar bahasa pertama (B1) dan dapat pula terjadi pada pelajar-bahasa yang sedang belajar bahasa kedua (B2).

Pada awalnya, dalam pembelajaran bahasa kedua, kesalahan berbahasa dikaji dengan Analisis Kontrastif (Contrastive Analysis). Analisis Kontrastif beranggapan bahwa belajar bahasa adalah membentuk kebiasaan (ber)bahasa. Menurut Analisis Kontrastif, sebelum belajar bahasa kedua, pelajar-bahasa telah menguasai bahasa pertamanya. Dengan demikian, sebenarnya, pelajar-bahasa telah memiliki kebiasaan berbahasa pertama. Artinya, pelajar-bahasa telah menguasai sistem bahasa pertama, misalnya, sistem kosakata, tatabahasa, dan pragmatiknya. Sistem bahasa pertama yang telah diinternalisasi dan dikuasai itu telah membentuk kebiasaan berbahasa.

Oleh karena pelajar B2 telah menguasai B1, saat belajar B2, mereka mentransfer kebiasaan B1 ke dalam B2. Jika ada ciri B1 yang sama dengan ciri B2, diasumsikan terjadi transfer positif. Jika ada ciri B1 yang berbeda dengan ciri B2, diasumsikan terjadi transfer negarif. Transfer negatif ini dinamakan interferensi. Menurut pandangan Analisis Kontrastif, interferensi merupakan penyebab utama terjadinya kesalahan B2.

Untuk memiminimalkan kesalahan berbahasa dalam belajar bahasa, perlu dilakukan Analisis Kontrastif. Prosedur Analsis Kontrastif adalah (1) deskripsi, yakni menyusun perian formal butir-butir linguistik dua bahasa (B1:B2); (2) seleksi, yakni butirbutir bahasa yang diduga menyebabkan kesalahan diseleksi untuk dibandingkan; (3) perbandingan, yaitu mengidentifikasi butirbutir bahasa yang berbeda dan yang sama; dan (4) peramalan, yaitu mengidentifikasi butirbutir linguistik yang mungkin menyebabkan terjadinya kesalahan.

Dalam meramalkan terjadinya kesalahan itu, dalam Analisis Kontrastif terdapat dua hipotesis, yakni hipotesis bentuk kuat dan hipotesis bentuk lemah. Hipotesis bentuk kuat menyatakan bahwa semua kesalahan berbahasa dapat diramalkan dengan Analisis Kontrastif, yakni semua perbedaan ciri B1 dan B2 pasti menyebabkan kesulitan dan kesulitan itu menyebabkan kesalahan. Kesalahan itu berupa interferensi B1 ke B2. Sebaliknya, hipotesis bentuk lemah 
menyatakan bahwa Analisis Kontrastif dapat digunakan untuk mengidentifikasi kesalahan yang disebabkan oleh interferensi. Analisis Kontrastif hanya untuk diagnostik. Prosedurnya, kesalahan diidentifikasi dengan menganalisis korpus bahasa pelajar-bahasa; kemudian Analisis Kontrastif menentukan kesalahan dengan membandingkan B2 dengan B1 pelajar-bahasa. Secara tersamar, hipotesis Analisis Kontrastif bentuk lemah ini mengakui tidak semua kesalahan berbahasa disebabkan oleh interferensi.

Pada perkembangannya, asumsi Analisis Kontrastif tersebut dipertanyakan. Ternyata, interferensi bukanlah satu-satunya penyebab kesalahan berbahasa. Bertitik tolak dari kelemahan Analisis Kontrastrif itulah, pada tahun 1970-an, Analisis Kesalahan bekembang sebagai bagian kajian linguistik terapan. Perkembangan itu ditandai oleh karya Analisis Kesalahan berbahasa oleh Corder. Corder menyatakan bahwa kesalahan berbahasa itu memiliki tiga fungsi berikut. Pertama, bagi guru, kesalahan berbahasa menunjukkan seberapa banyak pelajar-bahasa telah belajar (fungsi pedagogis). Kedua, bagi peneliti, kesalahan berbahasa menunjukkan bagaimana pelajar-bahasa belajar bahasa (fungsi metodologis). Ketiga, bagi pelajar-bahasa, kesalahan berbahasa menunjukkan bagaimana mereka menemukan dan menguasai suatu kaidah bahasa (fungsi proses pemerolehan bahasa). Hal ini disebabkan adanya perbedaan individual pembelajar (Robinson, 2002).

Corder (1981) menyebutkan 5 (lima) tahap penelitian Analisis Kesalahan, yakni mengumpulkan sampel bahasa pelajar-bahasa, mengidentifikasi kesalahan, mendeskripsikan kesalahan, menjelaskan kesalahan, dan menilai kesalahan. Akan tetapi, kebanyakan penelitian tidak memasukkan tahap 5, yakni menilai kesalahan. Pada umumnya, penilaian kesalahan bahasa dilakukan secara terpisah dengan metode penelitian tersendiri. Untuk itu, dalam tulisan ini dibahas 4 (empat) tahap penelitian Analisis Kesalahan berbahasa sebagaimana tertuang dalam paparan berikut ini.

\section{B. ME N G U M P UL KA N SA M P E L BAHASA PELAJAR-BAHASA}

Penelitian Analisis Kesalahan dimulai dengan menentukan sampel bahasa pelajarbahasa yang akan dianalisis dan menentukan prosedur mengumpulkan sampel itu. Berdasarkan ukurannya, sampel dapat dibedakan atas tiga jenis sampel, yakni sampel massal, sampel khusus, dan sampel insidental. Sampel massal merupakan sampel penggunaan bahasa yang dikumpulan dari banyak pelajarbahasa. Pengumpulan sampel ini bertujuan untuk memperoleh sampel kesalahan bahasa yang menyeluruh dan mewakili populasi (misalnya, dalam penelitian kuantitatif). Sampel khusus merupakan sampel yang diperoleh dari satu jenis penggunaan bahasa yang dituturkan oleh beberapa orang pelajarbahasa. Adapun sampel insidental merupakan sampel yang diperoleh dari satu penggunaan bahasa yang dituturkan oleh seorang pelajarbahasa.

Kesalahan berbahasa dipengaruhi oleh berbagai faktor. Sebagai contoh, pelajar-bahasa melakukan kesalahan berbahasa saat berbicara, tetapi bisa jadi dia tidak melakukan kesalahan saat menulis. Itu terjadi karena perbedaan proses berbahasa lisan dan tulis. Pelajar-bahasa dengan B1 bahasa Sunda menambahkan hamzah (glottal stop) pada vokal suku akhir kata Bahasa Indonesia, sedangkan yang ber-B1 bahasa Jawa tidak melakukannya. Pelajar berB1 bahaa Jawa menambakan bunyi sengau (nasal) pada nama tempat yang berkonsonan awal /b/, sedangkan yang ber-B1 bahasa Sunda tidak. Faktor-faktor yang berpengaruh terhadap sampel bahasa itu perlu diketahui agar peneliti dapat menjelaskan dengan tepat penyebab terjadinya kesalahan berbahasa.

Dua faktor penting perlu mendapatkan perhatian dalam mengumpulkan sampel bahasa, yakni karakteristik bahasa dan pelajar bahasa. Faktor bahasa yang perlu mendapatkan perhatian adalah medianya (lisan atau tulis), genre (percakapan, kuliah, uraian, surat, dst), dan isi (topik pembicaraan). Faktor diri pelajar bahasa yang perlu mendapatkan perhatian adalah tingkat kemahirannya (dasar, menengah, 
lanjut), bahasa pertama, dan pengalaman belajar bahasa (kelas formal, alamiah, atau gabungan keduanya)

Faktor cara pengumpulan sampel bahasa perlu pula diperhatikan. Sampel bahasa dapat dikumpulkan berdasarkan tuturan alamiah pada tuturan spontan atau tuturan hasil pancingan. Pada umumnya, peneliti lebih tertarik mengambil sampel tuturan alamiah. Akan tetapi, sering terjadi pelajar-bahasa tidak banyak menghasilkan tuturan spontan. Untuk itulah, peneliti dapat menggunakan data hasil pancingan. Pemancingan data harus dibedakan dengan penilaian. Penilaian menekankan pada pengukuran kemampuan berbahasa, sedangkan pemancingan berupaya menggali kompetensi bahasa.

Corder membedakan dua jenis pancingan, yakni pancingan klinis dan pancingan eksperimen. Pancingan klinis melibatkan informan untuk menghasilkan berbagai jenis data, misalnya, dengan wawancara atau menyuruh siswa menulis suatu karangan. Pancingan eksperimen dilakukan dengan menggunakan instrumen yang dirancang untuk memancing data yang berisi ciri-ciri linguistik yang diinginkan oleh peneliti. Contoh instrumen pemancing data adalah Bilingual Syntax MeasureBSMyang digunakan oleh Burt dkk (1973). BSM terdiri atas gambar berseri yang digunakan untuk memancing butir-butir bahasa tertentu. Pencipta instrumen ini mengatakan bahwa korpus data bahasa yang diperolehnya itu menggambarkan tuturan alamiah.

Teknik pengumpulan data itu berpengaruh pada data yang diperoleh. Sebagai contoh, Lococo (1976 dalam Ellis, 1995) menemukan perbedaan jumlah dan jenis kesalahan pada sampel bahasa saat menggunakan teknik pengumpulan data yang berbeda, yakni menulis bebas, menerjemahkan, dan menulis berdasarkan gambar. Misalnya, kesalahan berbahasa karena interferensi B1 banyak muncul pada data yang dikumpulkan dengan teknik terjemahan, yakni saat pelajarbahasa diberi tugas untuk menerjemahkan tuturan B1 ke B2.
Faktor lain yang perlu diperhatikan adalah retang waktu pengumpulan data, yakni secara cross-sectional ataukah longitudinal. Pengumpulan data secara cross-sectional dilakukan dengan mengambil data pada satu kesatuan waktu tertentu, sedangkan secara longitudinal dilakukan dengan mengambil data pada rentangan waktu yang cuku lama. Sebagian besar pengumpulan data untuk Analisis Kesalahan menggunakan crosssectional. Kelemahan cara ini adalah sulit menentukan secara tepat perbedaan kesalahan berbahasa pada tahapan perkembangan bahasa yang berbeda.

\section{MENGIDENTIFIKASI KESALAHAN}

Setelah korpus bahasa pelajar-bahasa dikumpulkan, kesalahan bahasa harus diidentifikasi. Untuk itu, perlu dijelaskanlan dulu pengertian kesalahan (error) dan prosedur mengenali kesalahan bahasa itu.

Kesalahan bahasa adalah penyimpangan penggunaan bahasa dari norma bahasa sasaran. Sehubungan dengan pengertian itu, empat hal berikut perlu diperhatikan. Pertama, ragam bahasa sasaran yang digunakan sebagai norma. Untuk keperluan praktisterutama untuk pengajaran bahasaragam bahasa sasaran yang digunakan sebagai norma adalah ragam bahasa tulis baku. Norma ini tentu tidak tepat jika digunakan untuk mengidentifikasi kesalahan bahasa lisan pelajar-bahasa. Tidak selamanya peneliti dapat dibenarkan mengadopsi bahasa tuturan tulis baku sebagai norma. Kenyataan menunjukkan bahwa banyak pelajar-bahasa memperoleh pajanan bahasa baik lisan maupun tulis yang berbeda dengan bahasa baku.

Kedua, perbedaan kesalahan (error) dan kekeliruan (mistake) (Corder, 1967). Secara teknis, kesalahan merupakan penyimpangan penggunaan bahasa karena pelajar-bahasa tidak mengetahui norma yang benar. Kesalahan merupakan perwujudan kekurangmampuan atau belum memiliki kompetensi berbahasa. Dengan kata lain, kesalahan merupakan fenomena kompetensi. Sebaliknya, kekeliruan terjadi jika pelajar- 
bahasa gagal mengungkapkan kompetensinya, padahal sebenarnya dia sudah menguasai norma bahasa tersebut. Keskeliruan menyangkut persoalan pemrosesan produksi bahasa, yakni kesulitan mengakses norma bakunya sehingga ia menggunakan bahasa nonbaku. Kekeliruan merupakan fenomena performansi, bukan kompetensi. Kekeliruan terjadi karena keterbatasan perencanaan, kekurangan ingatan, dan kehilangan mekanisme otomatis. Corder berpendapat bahwa Analisis Kesalahan memusatkan perhatian pada kesalahan, bukan kekeliruan. Karena itu, data kekeliruan bahasa dikesampingkan dari analisis.

Ketiga, ada kesalahan tampak dan ada kesalahan tersamar. Kesalahan tampak mudah diidentifikasi karena jelas-jelas menyimpang dari norma. Kesalahan tersamar terjadi pada ujaran yang secara lahiriah bentuknya apik, tetapi tidak sesuai dengan yang kelaziman atau tidak sesuai dengan maksud penutur.

Keempat, parameter kesalahan itu penyimpangan kebenaran/kebakuan bentuk bahasa ataukah ketepatan penggunaan bahasa. Penyimpangan kebakuan bahasa, lazimnya, berhubungan dengan penyimpangan kaidah bentuk, struktur, atau pola bahasa. Adapun penyimpangan dari ketepatan berkaitan dengan ketidakcocokan bentuk bahasa dengan konteks penggunaan bahasa. Pada awalnya, Analisis Kesalahan mengkaji kesalahan bentuk bahasa dan mengabaikan kesalahan penggunaan bahasa. Akan tetapi, akhir-akhir ini, Analisis Kesalahan juga mengkaji penggunaan bahasa.

Empat persoalan tersebut menunjukkan rumitanya mengenali kesalahan. Untuk itu, Corder (1971; 1974), mengajukan prosedur pengidentifikasian kesalahan sebagaimana tampak pada Diagram 1.

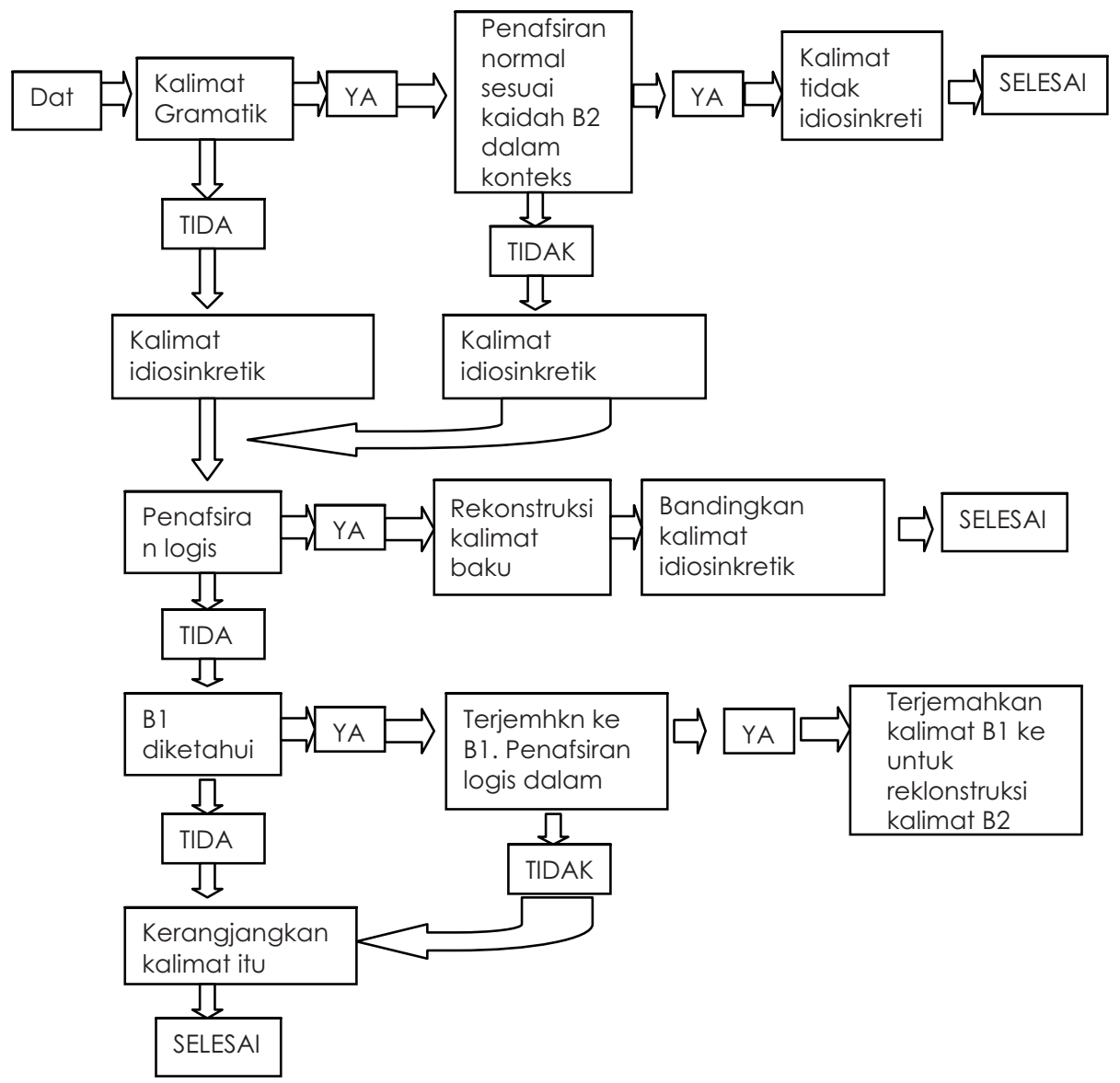

Diagram 1 Algoritma untuk Mendeskripsikan Dialek Ideosinkretik (Corder, 1981) 
Berdasarkan prosedur itu, diakui pentingnya 'penafsiran'. Untuk keperluan itu, ada tiga jenis penafsiran: normal, otoritatif, dan kelogisan. Penafsiran normal terjadi jika penganalisis dapat mengenali makna ujaran berdasarkan kaidah bahasa sasaran. Dalam hal ini, ujuran pelajar-bahasa "tidak menampakkan kesalahan". Penafsiran otoritatif dilakukan dengan cara menanyai pelajar-bahasa tentang makna ujarannya, kemudian peneliti merekonstruksinya. Penafsiran kelogisan dapat diperoleh dengan mengacu pada konteks ujaran pelajar-bahasa atau menerjemahkan kalimat secara harfiah dalam B1-nya.

Dalam praktiknya, ada sejumlah persoalan kerumitan teknis dan metodologis dalam prosedur pengidentifikasian kesalahan yang telah dikemukakan tersebut. Pertama, pembedaan kesalahan dengan kekeliruan bukanlah perkara mudah untuk diterapkan, sekalipun pelajar-bahasa dapat memberikan penafsiran otoritatif. Kedua, juga tidak mudah mengidentifikasi kesalahan tersamar. Mempercayakan pelajar sebagai informan perlu dicermati karena model retrospektif untuk menjelaskan makna, reliabilitasnya bisa diragukan. Ketiga, asumsi bahwa pelajarbahasa memiliki pengetahuan metalingual yang cukup untuk menjelaskan performansinya seringkali menghadapi kendala dalam praktik Analisis Kesalahan berbahasa, baik untuk pelajar anak-anak maupun pelajar dewasa.

\section{MENDESKRIPSIKAN KESALAHAN}

Mendeskripsikan kesalahan berarti menghubungkan ujaran pelajar-bahasa (idiosinkretik) dengan rekonstruksi ujaran dalam bahasa sasaran. Untuk itu, perhatian peneliti terarah pada piranti luar ujaran pelajarbahasa. Beberapa peneliti membedakan secara jelas antara mendeskripsikan kesalahan dengan menjelaskan kesalahan. Deskripsi Analisis Kesalahan itu hanya memfokuskan pada bentuk yang teramati atau kesalahan linguistik lahiriah. Deskripsi itu digunakan sebagai dasar untuk menjelaskan atau membahas kesalahan bahasa pelajar-bahasa.

Dasar klasifikasi kesalahan yang paling sederhana adalah berdasarkan katagori linguistik. Lazimnya, pengklasifikasian ini untuk tujuan pedagogis karena kategori linguistik itu berkaitan erat dengan silabus struktural dan buku teks bahasa. Berdasarkan kategori linguistik itu, kesalahan berbahasa dapat diklasifikasi atas kesalahan penggunaan klausa, sistem kata bantu, kalimat pasif, konjungsi, dan unsur-unsur kalimat yang lain. Pengklasifikasian itu dapat juga menggunakan kategori linguistik yang lebih umum, misalnya, kesalahan bidang morfologi, sintaksis, dan kosa kata. Lebih lanjut, dapat dideskripsikan lebih rinci ciri-ciri linguistiknya dan dapat pula dikuantifikasi kesalahan bahasanya.

Dulay, Burt, Krashen (1982) mengklasifikasi kesalahan penggunaan butirbutir bahasa berdasarkan taksonomi strategi lahiriah, yakni penghilangan, penambahan, salah bentukan, dan salah urutan Taksonomi ini dituangkan dalam Tabel 2 berikut.

Tabel 2: Taksonomi Strategi Lahiriah Kesalahan Bahasa

(Dikutip dari Dulay, Burt, dan Krashen, 1982)

\begin{tabular}{|l|l|l|}
\hline Kategori & Deskripsi & Contoh \\
\hline Penghilangan & $\begin{array}{l}\text { Menghilangkan butir bahasa yang } \\
\text { seharusnya ada }\end{array}$ & She sleeping \\
\hline Penambahan & $\begin{array}{l}\text { Menambahkan butir bahasa yang } \\
\text { seharusnya tidak ada }\end{array}$ & We didn't went threre \\
\hline Salah bentukan & $\begin{array}{l}\text { Salah menggunakan bentuk bentuk } \\
\text { morfem dan struktur kalimat }\end{array}$ & The dog ated the chicken \\
\hline Salah urutan & $\begin{array}{l}\text { Salah menempatkan morfem atau } \\
\text { kelompok morfem }\end{array}$ & What daddy is doing? \\
\hline
\end{tabular}

diksi Vol. : 15 No. 1 Januari 2008 
Sekalipun taksonomi linguistik dan taksonomi strategi lahiriah kesalahan bahasa tersebut berkaitan dengan terapan pedagogismisalnya, dengan ditemukannya kesalahan anak, berarti guru harus memberikan perhatian yang lebih pada kesalahan itupada umumnya, para peneliti belum banyak memberikan perhatian pada bagaimana proses belajar B2. Corder mengajukan kerangka kerja proses belajar B2 itu. Dia membedakan tiga jenis kesalahan berdasarkan tingkat kesistematisannya, yakni kesalahan prasistematis, kesalahan sistematis, dan kesalahan pascasistematis. Kesalahan prasistematis terjadi ketika pelajar-bahasa tidak menyadari adanya kaidah tertentu dalam bahasa sasaran. Kesalahan ini acak. Kesalahan sistematis terjadi ketika pelajar-bahasa telah memahami suatu kaidah bahasa, tetapi dia salah menggunakannya. Kesalahan pasacasistematis terjadi ketika pelajar-bahasa mengetahui kaidah bahasa yang benar, tetapi dia menggunakannya secara tidak ajeg (dalam hal ini disebut kekeliruan).

Untuk mengidentifikasi jenis kesalahan tersebut, peneliti harus mewawancarai pelajar-bahasa. Dengan demikian, disebut jenis kesalahan prasistematis jika pelajar-bahasa tidak dapat memberikan alasan mengapa dia menggunakan bentuk bahasa tertentu. Disebut jenis kesalahan sistematis jika pelajar-bahasa tidak mampu membetulkan kesalahan yang dia buat, tetapi dia dapat menjelaskan kesalahan penggunaan kaidah bahasa. Disebut jenis kesalahan pascasistematis jika pelajar-bahasa dapat menjelaskan kaidah bahasa sasaran yang digunakan dan dia bisa menggunakannya saat diberi tugas. Cara kerja tersebut mempersyaratkan peneliti memiliki akses dengan pelajar-bahasa dan pelajar-bahasa mampu memberikan penejalasan atas tuturan B2-nya. Berdasarkan alasan tersebut, cara kerja tersebut sulit untuk dilaksanakan.

\section{E. MENJELASKAN KESALAHAN}

Setelah peneliti mengidentifikasi dan mendeskripsikan kesalahan, tahap berikutnya adalah menjelaskan kesalahan. Kegiatan menjelaskan ini berkaitan dengan menentukan sumber-sumber kesalahan, yakni menjawab pertanyakaan mengapa kesalahan itu terjadi. Tahapan ini sangat penting dalam penelitian pemerolehan B2 karena dalam tahap ini peneliti berupaya menjelaskan proses pemerolehan B2.

Sumber kesalahan bahasa itu mungkin menyangkut aspek psikolinguistik, sosiolinguistik, epistemik, atau struktur kewacanaan tuturan. Aspek psikolinguistik berupaya menjelaskan hakikat sistem B2 pelajar-bahasa dan kesulitan-kesulitannya dalam menuturkan bahasa sasaran. Aspek sosiolinguistik berupaya menjelaskan kemampuan pelajar-bahasa menyesuaikan bahasanya berdasarkan konteks sosial. Aspek epistemik berupaya menjelaskan kekurangmampuan pelajar-bahasa pada bidang pengetahuan tentang dunia. Adapun aspek wacana berupaya menjelaskan pengorganisasian informasi ke dalam teks yang koheren (lihat Schiffrin, 2007).

Pada umumny, penelitian pemerolehan B2 memusatkan perhatian pada aspek yang pertama, yakni aspek psikolinguisitik. Tujuan Analisis Kesalahan memberikan penjelasan aspek psikologis ini. Diagram 2 mengkerangkakan aspek psikolinguistik tersebut. 


\section{Diagram 2: Sumber Kesalahan Berdasarkan Aspek Psikolinguistik}

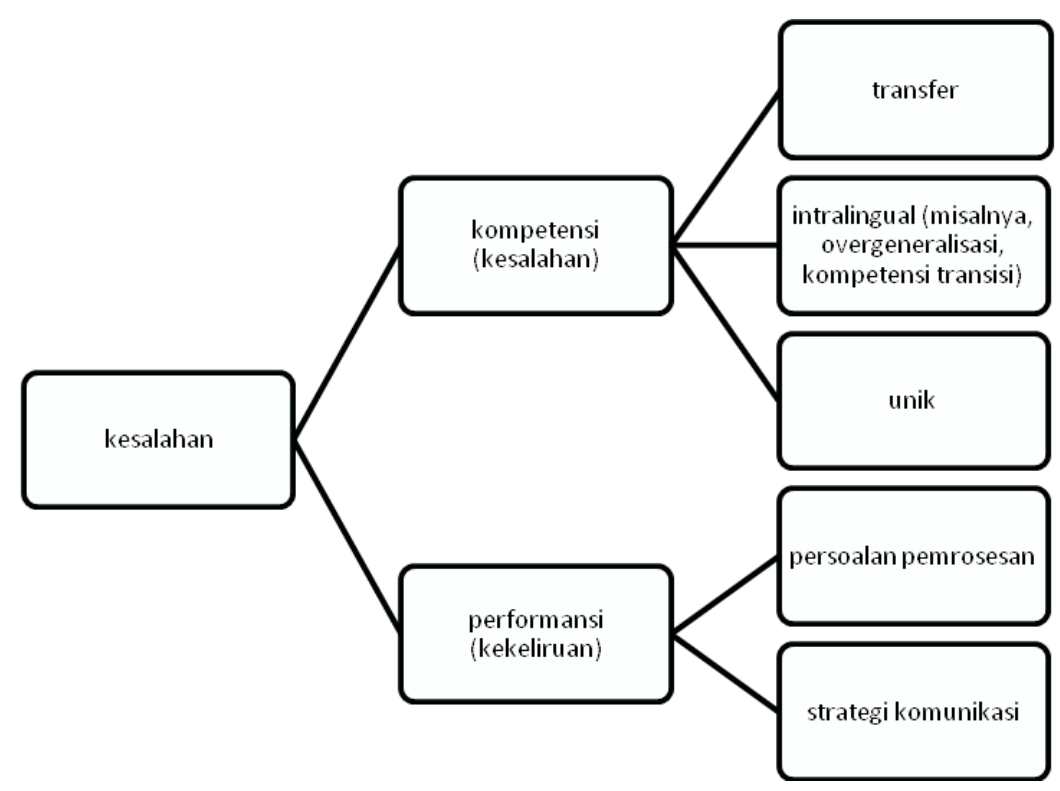

Perbedaan kesalahan dan kekeliruan sebagaimana yang telah dibahas sebelumnya, dapat juga dijelaskan sebagai berikut. Setiap penyimpangan penggunaan bahasa itu merefleksikan adanya persoalan performansi atau persoalan kompetensi. Setidaknya, ada tiga penyebab kesalahan kompetensi yang dapat diidentifikasi. Pertama, kesalahan karena interferensi, yakni penggunaan unsur dari satu bahasa saat menggunakan bahasa yang lainnya. Kedua, kesalahan intralingual, yakni refleksi karakteristik umum kaidah belajar misalnya generalisasi yang berlebihan, terapan kaidah yang belum sempurna, dan kegagalan menerapkan kaidah sesuai dengan konteks yang seharusnya. Ketiga, kesalahan perkembangan, yakni kesalahan yang disebabkan oleh upaya pelajar-bahasa untuk membangun hipotesis tentang bahasa sasaran berdasarkan keterbatasan pengetahuan dan pengalamannya.

Peneliti lain menyebutkan adanya kesalahan transfer untuk menjelaskan kesalahan interferensi. Kesalahan transfer dapat dibagai atas tiga jenis kesalahan, yakni analogi berlebihan, transfer struktur, dan kesalahan inter/intralingual. Kesalahan yang bersumber dari analogi berlebihan terjadi saat pelajar-bahasa salah menggunakan butir-butir bahasa karena adanya kemiripan penggunaan dalam bahasa pertamanya. Kesalahan karena transfer struktur terjadi bila pelajar-bahasa menggunakan ciri-ciri B1 (fonologis, leksikal, tatabahasa, atau pragmatik) dalam B2 yang dipelajarinya. Adapun kesalahan interl/intralingual muncul karena ciri-ciri tertentu tidak ada dalam B1 tetapi harus ada dalam B2. Kesalahan intralingual dapat dibedakan atas empat kategori, yakni kesalahan generalisasi berlebihan, pengabaian kaidah tertentu, terapan kaidah yang tidak lengkap, dan hipotesis salah konsep. Ada tiga jenis sumber kesalahan, yakni kesalahan perkembangan (kesalahan yang mirip dengan pemerolehan B 1), interferensi (kesalahan yang mencerminkan struktur B1), unik (kesalahan yang tidak dapat dikategorikan pada kesalahan perkembangan dan kesalahan interferensi).

\section{F. PENUTUP}

Sebagai penutup, perlu dikemukakan keterbatasan Analisis Kesalahan dan ringkasan pembahasan tersebut dia atas. Analisis Kesalahan memiliki kelemahan dalam menggambarkan secara utuh bahasa pelajarbahasa. Dalam bahasa pelajar-bahasa terdapat 
banyak penggunaan bahasa yang benar, di samping memang terdapat kesalahan berbahasa. Dengan perkataan lain, untuk menggambarkan dan menjelasakan bahasa pelajar-bahasa, penggunaan bahasa yang benar yang diproduksi oleh pelajar-bahasa perlu dipaparkan dan digambarkan, bukan hanya kesalahannya saja.

Ellis (1995) menyatakan bahwa Analsisis kesalahan berbahasa merupakan salah satu metode yang digunakan untuk meneliti bahasa pelajar-bahasa. Metode ini merupakan pengganti dari metode Analisis Kontrastif. Tahap pertama prosedur Analisis Kesalahan adalah mengumpulkan sampel massal, khusus, atau insidental bahasa pelajarbahasa. Sampel bahasa dikumpulkan melalui tuturan alamiah atau melalui pemancingan. Rancangan penelitian yang digunakan dapat berupa rancangan cross-sectional atau longitudinal. Tahap kedua adalah mengidentifikasi kesalahan bahasa sampel. Analisis difokuskan pada kesalahan, bukan kekeliruan. Prosedur identifikasi kesalahan dapat dilakukan dengan penafsiran normal, otoritatif, dan kelogisan. Tahap ketiga adalah deskripsi kesalahan. Untuk mendeskripsikan kesalahan dapat menggunakan taksonomi linguistik atau strategi lahiriah. Taksonomi linguistik untuk mengklasifikasi keslalahan berdasarkan hierarkhi kebahasaan (kosakata, morfologi, kalimat) atau kategori khusus butirbutir kebahasaan (penggunaan kata ganti, preposisi, urutan kata, misalnya). Taksonomi strategi lahiriah berupa klasifikasi kesalahan karena penghilangan, penambahan, salah bentuk, dan salah urut. Tahap keempat adalah menjelaskan kesalahan berbahasa sebagai proses psikolinguistik. Kesalahan berbahasa dapat dijelaskan sebagai hasil proses transfer, intralingual, atau unik.

\section{DAFTAR PUSTAKA}

Burt, M., Dulay, E.,dan Hernandez, E. 1973. Bilingual Sintax Measure. New York: Harcourt Brace Javanovich.

Corder, S.P. 1981. 'Idiosyncratic dialects and error analysis'. Dalam International Review of Applied Linguistic 9.

Corder, S.P. 1981. Error Analysis and Interlanguage. Oxford: Oxford University Press.

Dulay, H., Burt, M., Krashen, S.D. 1982. Language Two. New York. Oxford University Press.

Dulay, H., dan Burt, M. 1994. 'Error and strategies in child second language acquisition'. Dalam TESOL Quarterly 8.

Ellis, R. 1995. The Study of Second Language Acquisition. Oxford: Oxford University Press.

Robinson, Peter. 2002. Individual Differences and Instructed Language Learning. Amsterdam: John Benyamins Publishing Company.

Schiffrin, Deborah. 2007. Ancangan Kajian Wacana. Terjemahan Abd. Syukur Ibrahim (ed). Yogyakarta: Pustaka Pelajar. 